AL IBTIDA: JURNAL PENDIDIKAN GURU MI (2019) Vol 6 (1) : 1-18

DOI: http://dx.doi.org/ 10.24235/al.ibtida.snj.v6i1.3658

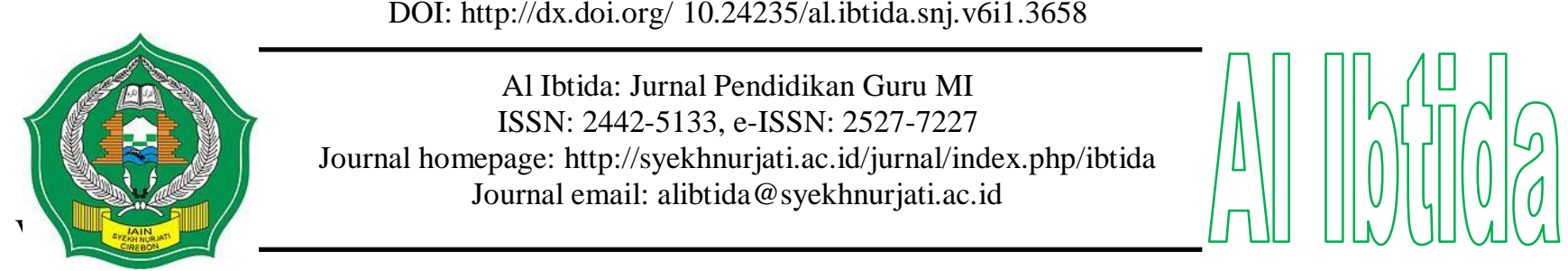

\title{
Analyzing Madrasah Ibtidaiyah Teacher Candidates Skill of Technological Pedagogical Content Knowledge on Natural Science Learning
}

\author{
Juhji* \\ *Department of Madrasah Ibtidaiyah Teacher Education, Faculty of Tarbiyah and Teacher Training, \\ Universitas Islam Negeri Sultan Maulana Hasanuddin Banten \\ Email: juhji@uinbanten.ac.id
}

Received: December 12 ${ }^{\text {th }}, 2018$. Accepted: April 26 ${ }^{\text {th }}, 2019$. Published: June $30^{\text {th }}, 2019$.

\begin{abstract}
This study aims to determine the ability of Technological and Pedagogical Content Knowledge of prospective teachers of primary school at science subject. Respondents of this study were prospective teachers of the primary school in UIN Sultan Maulana Hasanuddin Banten in the academic year 2018/2019 which took the Practice Program Course of Employment in the semester VII. The method used in this study is a type of survey cross-sectional design. The research instruments include a closed questionnaire, analysis of lesson plans, and observation sheet. The data obtained in this study is the description of Technological Pedagogical Content Knowledge at Science Subject. The results showed that the mean skill score technological knowledge prospective teachers primary school of 2.94 (good category), average skill score pedagogical knowledge for prospective teachers primary school is 2.86 (good category), average skill score content knowledge for prospective teachers of primary school is 2.66 (good category), average skill score pedagogical content knowledge prospective teachers of primary school are 3.02 (good category), average skill score technological content knowledge prospective teachers of primary school of 2.41 (a quite good category), average skill score of technological pedagogical knowledge prospective teachers of primary school is 2.65 (good category), average skill score of TPCK prospective teachers of primary school is 2.38 (category pretty good). Thus, it can be concluded that the ability of Technological Pedagogical Content Knowledge Prospective Teachers of Primary School in Science Subjects has a pretty good category.
\end{abstract}

Keywords: prospective teachers of madrasah Ibtidaiyah, science learning, technological pedagogical content knowledge.

\begin{abstract}
Abstrak
Penelitian ini bertujuan untuk mengetahui kemampuan Technological Pedagogical Content Knowledge calon guru Madrasah Ibtidaiyah pada pembelajaran Ilmu Pengetahuan Alam (IPA). Responden penelitian adalah mahasiswa calon guru Madrasah Ibtidaiyah di UIN Sultan Maulana Hasanuddin Banten tahun akademik 2018/2019 yang mengambil mata kuliah Program Praktik Lapangan Kerja (PPLK) di semester VII. Metode yang digunakan dalam penelitian ini adalah survei dengan tipe cross sectional design. Instrumen penelitian berupa angket tertutup, lembar analisis
\end{abstract}


dokumen RPP, dan lembar observasi. Data yang diperoleh berupa deskripsi tentang Technological Pedagogical Content Knowledge pembelajaran IPA. Hasil penelitian menunjukkan bahwa rata-rata skor keterampilan technological knowledge calon guru Madrasah Ibtidaiyah sebesar 2,94 (kategori baik), rata-rata skor keterampilan pedagogical knowledge calon guru Madrasah Ibtidaiyah sebesar 2,86 (kategori baik), rata-rata skor Keterampilan content knowledge calon guru Madrasah Ibtidaiyah sebesar 2,66 (kategori baik), rerata skor keterampilan pedagogical content knowledge calon guru Madrasah Ibtidaiyah sebesar 3,02 (kategori baik), rata-rata skor keterampilan technological content knowledge calon guru Madrasah Ibtidaiyah sebesar 2,41 (kategori cukup baik), rata-rata skor keterampilan technological pedagogical knowledge calon guru Madrasah Ibtidaiyah sebesar 2,65 (kategori baik), rata-rata skor keterampilan technological pedagogical content knowledge calon guru Madrasah Ibtidaiyah 2,38 (kategori cukup baik). Dengan demikian, dapat disimpulkan bahwa kemampuan Technological Pedagogical Content Knowledge calon guru Madrasah Ibtidaiyah pada pembelajaran IPA memiliki kategori yang cukup baik.

Kata kunci: calon guru madrasah ibtidaiyah, pembelajaran ipa, technological pedagogical content knowledge.

\section{INTRODUCTION}

A teacher is the figure associated with students. The task belongs to a teacher is not just to transfer knowledge from teacher to learner (transfer of knowledge). Moreover, the teacher has some tasks, including planning and implementing the learning process that has been designed in lesson plans, assessing the results of learning, conducting guidance and training, conducting research and assessment of the problems found in learning. However, in some places there are still teachers who have not been optimal in carrying out their duties, such as not making lesson plans due to: 1) teacher lesson plans designed by others, 2) focused teacher attention to student graduation, 3) limited hours of study, 4) depending on the situation and conditions of the supervisor, 5) curriculum changes, 6) learning media is lacking, and 7) learning resources are lacking (Arna, 2014). Accordingly, it can be stated that the teachers are not optimal in carrying out their duties and functions.

In the process of learning and teaching in the madrasa, the teacher must be able to convey the material well because learning is essentially a process of developing new knowledge, skills, and behavior in an individual as a result of his interaction with various information and environment. Therefore, the teacher should be able to convey the message he knows correctly, through good pedagogical activities. However, there are still teachers who have not mastered the concept or teaching material correctly. This is indicated by the average score of the results of competency tests for elementary, junior high school, senior high school and/or vocational school teachers in 2017 in Banten Province as follows: 
Table 1. The average score of the results of teacher competency test in Banten province

\begin{tabular}{|c|c|c|c|c|c|}
\hline No. & Region code & $\begin{array}{l}\text { The name of the } \\
\text { region }\end{array}$ & Province & Pedagogic & Professional \\
\hline 491 & 280100 & Kab. Pandeglang & Banten & 48.55 & 52.85 \\
\hline 492 & 280200 & Kab. Lebak & Banten & 49.34 & 54.02 \\
\hline 493 & 280300 & Kab. Tangerang & Banten & 51.36 & 57.48 \\
\hline 494 & 280400 & Kab. Serang & Banten & 50.05 & 54.89 \\
\hline 495 & 286000 & Kota Cilegon & Banten & 55.06 & 60.73 \\
\hline 496 & 286100 & Kota Tangerang & Banten & 53.78 & 61.40 \\
\hline 497 & 286200 & Kota Serang & Banten & 53.37 & 59.01 \\
\hline 498 & 286300 & $\begin{array}{l}\text { Kota Tangerang } \\
\text { Selatan }\end{array}$ & Banten & 56.27 & 64.37 \\
\hline \multicolumn{4}{|c|}{ Average score in Province } & 52.17 & 58.05 \\
\hline \multicolumn{4}{|c|}{ National average score } & 50.43 & 55.46 \\
\hline \multicolumn{4}{|c|}{ National minimal standard of teacher competency test } & 55.00 & 55.00 \\
\hline
\end{tabular}

From table 1, it can be understood that the average score of the Teacher Competency Test (UKG) in Banten Province for pedagogical competence is still far below the minimum standard of the targeted national teacher competency test $(52.17<55.00)$. The average of national teacher competency test (50.43) is also below the minimum standard of the national teacher competency test that has been targeted even though the average score of professional competency has reached the minimum standard of the national teacher competency test. From these data, it can be assumed that mastery of content has not been comprehensively controlled. Thus, mastery of content or material is very important for a teacher so there is no misconception. The research conducted by Murtiningsih, Susilaningsih, \& Sohidin (2014) revealed that there was a positive contribution of mastery of material to the readiness to become a teacher

Shulman as cited by Kocoglu (2009) highlights that teaching content knowledge and knowledge of pedagogic content identified specific parts of a knowledge concept to teaching activities. Pedagogical Content Knowledge or PCK is a form of content and pedagogic integration in understanding how certain concepts can be represented and adapted to the interests and abilities of diverse students. Content and pedagogical knowledge is the easiest category to distinguish understanding of specialist content from an educator (Koçoğlu, 2009). The integration of learning technology into the PCK resulted in the TPCK concept, better known as the Technological Pedagogical Content Knowledge.

Technological Pedagogical Content Knowledge (TPCK) is knowledge about how to facilitate students from certain content (materials or concepts) through pedagogical and technological approaches (Cox \& Graham, 2009). TPCK was considered as a framework that has the potential to be able to provide solutions for teachers in solving learning problems related to 
the integration of technology, information and computers into the learning process carried out both in the classroom and outside the classroom.

TPCK in science learning is the use of technology by science teachers in teaching material or concepts of science learning. The integration of technology in teaching is important as an answer to the challenges of the globalization era which is characterized by the rapid development of Information and Communication Technology (ICT) (Sumintono, Wibowo, Mislan, \& Tiawa, 2012). Technology can also help teachers in their professional development, such as with the internet the teacher can search for the latest information or issues regarding the world of education, learning strategies, and the development of science in accordance with the fields that they have (Yaumi, 2011). The development of fundamental information and science in the era of globalization has become a challenge that must be addressed by teachers by promoting professionalism.

The teacher is the spearhead of education, meaning that the success of an educational institution can be determined by the teacher. There are several teacher functions that relate to their duties as educators, among them are as informants, organizers, motivators, directors, initiators, facilitators, and so forth. To carry out this function, the teacher must have several competencies. According to Government Regulation of the Republic of Indonesia Number 74 of 2008 Article 3 concerning Teachers explains that there are 4 (four) competencies that must be possessed by a teacher, namely pedagogic competence, personality competence, social competence, and professional competence (PP No. 74 of 2008).

In pedagogic competence, it contains points which are abilities that must be possessed by a teacher, namely the use of learning technology. This is stated in PP No. 74 of 2008 concerning Teachers article 3 paragraph 4 (f) which states that the ability of teachers in the management of learning of students includes: (a) understanding of insights or educational basis, (b) understanding of students, (c ) development of curriculum or syllabus, (d) learning planning, (e) implementation of educational and dialogical learning, (f) utilization of learning technology, (g) evaluation of learning outcomes, and (h) development of students to actualize their various potentials (PP No. 74 of 2008). Referring to these rules, the use and mastery of Information and Communication Technology (ICT) is a necessity and a very important requirement in the industrial era 4.0. If someone wants to advance, one of them must master technology. Therefore, it is only natural for a teacher to be required to have competence in the use of learning technology as stated in the teacher's competence.

The use of information and communication technology in learning is a must. The development of learning by integrating information and communication technology makes a real contribution to pedagogical practices towards the development of students. Mastery of 
information and technology literacy in science learning in madrasas or schools with various methods and approaches to learning in the classroom is a must. Teachers must be able to integrate technology into their teaching in the classroom. Therefore, it takes an approach or method that imposes teaching as an interaction between what teachers know and how they apply what they know in interesting circumstances or contexts in their classrooms. There is no "one best way" to integrate technology into the curriculum. Instead, integration efforts must be designed creatively or structured for specific learning and important ideas in the context of a class (Koehler \& Mishra, 2009).

Some research results indicate that the application of digital technology in the learning process can help improve students 'understanding of the content in the curriculum (Rau, Gao, \& $\mathrm{Wu}, 2008$ ). Also, it can increase learners' motivation and their interest in the subject matter taught in the curriculum (Owusu, Monney, Appiah, \& Wilmot, 2010). This study aims to describe the ability technological pedagogical content knowledge of prospective madrasah ibtidaiyah teachers in science learning. This research is expected to provide theoretical benefits, namely to support scientific development in the field of education of Madrasah Ibtidaiyah teachers and to add to the repertoire of scientific studies in developing mastery of technology, pedagogy, and content of science materials in Madrasah Ibtidaiyah.

\section{METHODS}

This research is descriptive exploratory research. The method used is a survey with a cross sectional design type (Creswell, 2009). The data obtained in this study is a description of data for Technological Pedagogical Content Knowledge of the 7th semester candidates for Madrasah Ibtidaiyah teachers in PGMI FTK UIN Study Program, Sultan Maulana Hasanuddin Banten, in the academic year of 2018/2019. Respondents are recruited by utilizing probability sampling technique while the method used in the determination of respondents is simple random sampling. The total population is 98 students spread in three classes namely class A as many as 34 students, class B as many as 32 students, and class C as many as 32 students. The determination of sample size in this study is based on a formula developed by Isaac and Michael (Sugiyono, 2017).

The requirements that must be met by students to be able to take PPLK courses are as follows: 1) registered as an active student in the semester PPLK is implemented, 2) has attended and obtained a minimum grade $\mathrm{C}$ in the skills and skills courses such as: Education Basics, Psychology Learning, Basics of Guidance and Counseling, Management of Education, Learning Methodology, Learning Media, Learning Planning, Teaching and Learning Strategies, Educational Evaluation, and Microteaching, 3) have followed the courses required by the 
department concerned, and 4) are required to follow orientation and PPLK advocates before going to madrasas or schools (Tim Penyusun, 2018).

The research instrument uses three types of instruments, namely: 1) closed questionnaire instrument, 2) RPP document analysis sheet, and 3) observation sheet. The closed questionnaire instrument consisted of 70 items including 14 items about Technological Knowledge (TK), 14 items of Pedagogical Knowledge (PK), 14 items of Content Knowledge (CK), 7 items of Pedagogical Content Knowledge (PCK), Technological Content Knowledge (TCK) of 7 items, Technological Pedagogical Knowledge (TPK) of 7 items, and Technological Pedagogical Content Knowledge (TPCK) of 7 items. Questionnaire enclosed in this study was adapted from a questionnaire has been developed by Schmidt et.al (Kabakci Yurdakul et. al., 2012; Sahin, 2011; Schmidt et al., 2009).

Data analysis of questionnaire validity is done through Pearson Correlation, while questionnaire reliability uses Cronbach's alpha test with SPSS version 16.0. The research data were analyzed descriptively, namely by describing the condition of the respondents. The results of the questionnaire validity analysis indicate that all statement items are declared valid. While the results of test Cronbach's alpha with SPSS version 16.0 obtained an alpha value of 0.889 which indicates that the questionnaire used is reliable (reliable).

Giving scores on questionnaires has gradations ranging from the positive to the negative with the words Strongly Agree (SS), Agree (S), Disagree (TS), Strongly Disagree (STS) given a score of 4, 3, 2, and 1. While giving a score on the Learning Implementation Plan (RPP) using number 1 if the RPP made by the respondent has met the variables TK, PK, CK, PCK, TCK, TPK, and TPCK. While the number 0 if the RPP made by the respondent does not meet the variables TK, PK, CK, PCK, TCK, TPK, and TPCK. The questionnaire data from the results of the research collected were then analyzed descriptively by looking for averages, standard deviations, percentage of questionnaire results, and consulted with the criteria that had been set. The criteria referred to were adopted from (Sugiyono, 2013).

\section{RESULTS AND DISCUSSION}

\section{Technological Knowledge (TK) of Prospective Madrasah Ibtidaiyah Teachers}

Knowledge Technologies (Technological Knowledge) is a knowledge of the different types of technologies ranging from software (software), hard ware (hardware) down to how to use it. Knowledge of technology as knowledge of a wide variety of technologies ranging from simple technologies such as paper, pencils, rulers to more complex technologies such as the internet, digital video, and computers (Wiguna, Fitri, \& Erlidawati, 2017).

Based on the analysis, obtained data scores for Technological Knowledge Prospective 
Madrasah Ibtidaiyah teachers in science learning are listed in table 2.

Table 2. Skor Angket TK Calon Guru Madrasah Ibtidaiyah pada Pembelajaran IPA

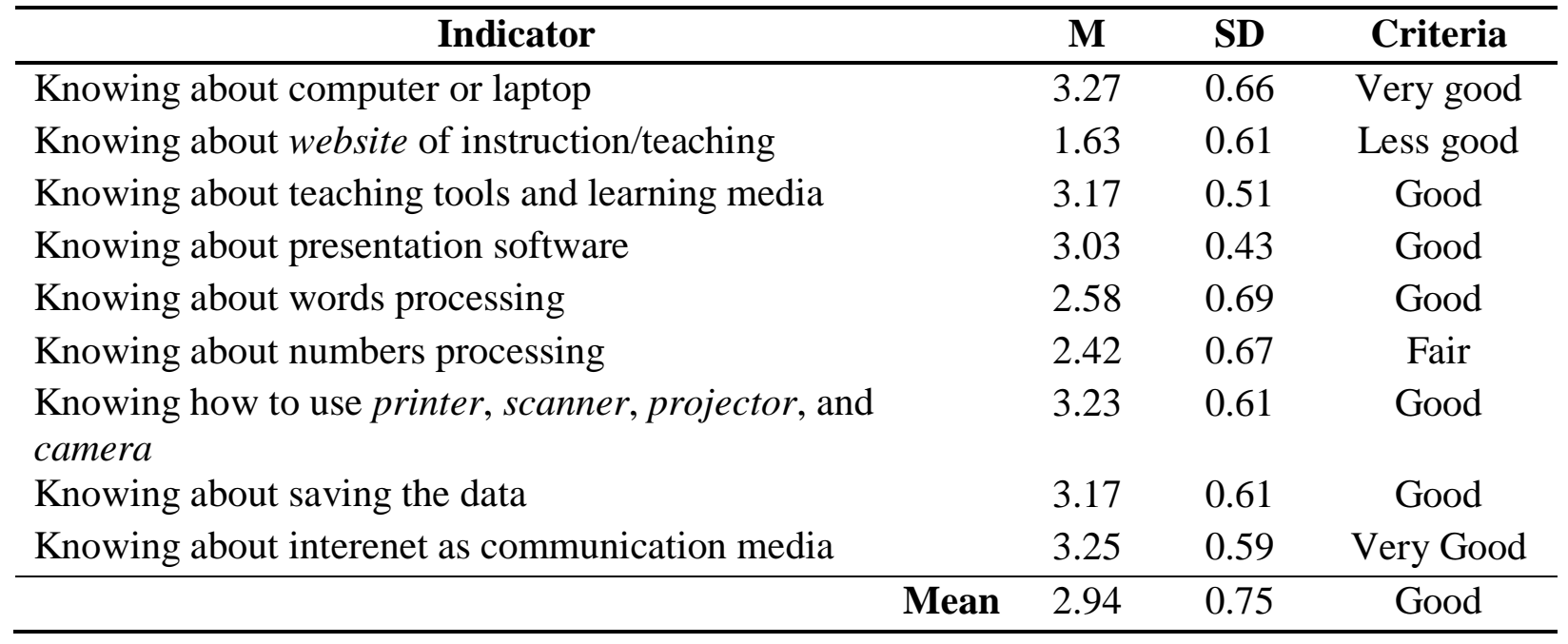

Based on the table 2 above, there are indicators that have very good category namely indicators knowing about computers a knows laptops and indicators know about the use of the internet as a communication medium, while indicators that have good categories are the 3rd, 4th, 5th, 7th, and 8th indicators. The indicator that gets a fairly good category is knowing about the number processing program and the indicator that gets the bad category is knowing about the website learning. In general, the technological knowledge of prospective Madrasah Ibtidaiyah teachers of UIN Sultan Maulana Hasanuddin Banten on Science Learning is good.

There are categorical indicators that are not good, namely the second indicator (knowing about the website learning). This is possible because there are not many madrasa teacher students who know a number of websites that can be used in the learning process in the classroom. The introduction of several websites learning can be included in research and scientific writing courses as embodied in the KKNI curriculum documents of Sultan Maulana Hasanuddin Banten's PGMI UIN study program on the achievement of 4th learning which is able to build knowledge, technology, and or art in the field of basic education or practice basic education professionals through innovative and tested research.

Ling Koh, Chai, \& Tay (2014) emphasize that the integration of technology into the learning process carried out by teachers is very important, although some teachers assume that the availability of computers in the classroom is one reason why teachers do not use the technology. But for teachers who are highly motivated, they will adapt to technological developments because new technologies are very important.

From table 2, it can be concluded that the technology knowledge (TK) of prospective MI teacher students is in a good category (2.94). The use of technology in the learning process in the class will be the greatly affect the learning outcomes of students. As Valanides (2014) has 
written in his book that the use of technology in classrooms and speculation about technology can affect the learning process of students. The results of the study by Edy (2012) also found that the application of information and communication technology or ICT in learning would be able to improve student learning outcomes, as well as the results of research by Yusri (2016) who found that the use of Information and Communication Technology (ICT) in the learning process done by the teacher can provide benefits in increasing the enthusiasm, passion, and desire of students in learning.

\section{Pedagogical Knowledge (PK) of Prospective Madrasah Ibtidaiyah Teachers}

Pedagogical Knowledge refers to the teacher's knowledge of the methods and the learning process including about classroom management (management class), assessment (evaluation), the development of learning tools, the management of learners, and an understanding of the learning process teaching done by students (Schmidt et al., 2009). Planning, implementation, and assessment in the learning process carried out by the teacher becomes the main foundation in understanding whether the teacher has good pedagogical knowledge or not. This knowledge becomes an important part that must be mastered by the teacher because one of the main tasks of the teacher is to design learning marked by making a Learning Implementation Plan (RPP), implementing learning in accordance with the plans that have been made, and assessing the results of the learning done authentically.

The same definition of pedagogical knowledge is also conveyed by Koehler, Mishra, Kereluik, Shin, \& Graham (2014), namely the teacher's knowledge of various implementations, strategies, and methods to support student learning. This understanding emphasizes the meaning that pedagogical knowledge is comprehensive (comprehensive) knowledge of the process and practice in teaching which includes various knowledge about classroom management, management of students, planning of learning, implementation of learning, and assessment or evaluation of learning. Pedagogical knowledge includes the use of methods, models, approaches to media knowledge, types of media, and media development, selection of domains and evaluation tools, and improvement of learning strategies.

The score of data for pedagogical knowledge prospective Madrasah Ibtidaiyah teachers in science learning can be seen in table 3 below. 
Table 3. The score of Pedagogical Knowledge questionnaire of prospective teachers of Madrasah Ibtidaiyah in natural science stream

\begin{tabular}{|c|c|c|c|}
\hline Indicator & $\mathbf{M}$ & SD & Criteria \\
\hline Knowing various teaching approach and strategies & 2.98 & 0.62 & Good \\
\hline Knowing various assessment methods and techniques & 3.07 & 0.48 & Good \\
\hline Knowing classroom management well & 2.87 & 0.58 & Good \\
\hline Knowing how to assess students' performance in the classroom & 3.19 & 0.67 & Good \\
\hline $\begin{array}{l}\text { Knowing about the possibility of misconceptions and } \\
\text { difficulties faced by students }\end{array}$ & 2.42 & 0.76 & Fairly good \\
\hline $\begin{array}{l}\text { Knowing the follow-up activities as efforts to improve the next } \\
\text { instructions }\end{array}$ & 2.40 & 0.82 & Fairly good \\
\hline Mean & 2.86 & 0.71 & Good \\
\hline
\end{tabular}

Profile data Pedagogical Knowledge as found in table 3, can be analyzed that pedagogical knowledge of prospective student teachers Madrasah Ibtidaiyah UIN Sultan Maulana Hasanuddin Banten is in the good category. This is indicated by the acquisition of an average questionnaire score of 2.86 with a standard deviation of 0.71 . That is, in general the respondents were (student candidates for Madrasah Ibtidaiyah teachers) are able to know the various approaches and learning strategies, know the management of the class, and know the assessment of the performance of students in the class properly.

Meanwhile, on the 5th and 6th indicators, the respondents 'knowledge about the possibility of misconceptions or conceptual errors and learners' difficulties and knowledge of the follow-up plan as an effort to improve the quality of learning are in a fairly good category. This is indicated by the acquisition of a mean score of 2.42 and 2.40 with a standard deviation of 0.76 and 0.82 , respectively. Therefore, further studies are needed on the analysis of misconceptions and plans for follow-up on related subjects so that students can have that knowledge well.

Based on table 3, it can be concluded that pedagogical knowledge of prospective MI teacher students is in a good category (2.86). Pedagogic knowledge of prospective teachers will influence the learning outcomes of students when they are directly involved in the learning process in the classroom. This is in line with the results of research conducted by Sari who found that the pedagogical competence of the teacher influences the learning outcomes of students. This is indicated by the price of $\mathrm{t}$ count of 13,279 which is greater than table of 12.706 at the significance level of less than 5\% (Sari, 2013). Likewise, the results of the research conducted by Andriawati, Mashudi, \& Utomo (2013) found that 43.3\% of students' learning outcomes were influenced by teacher's competency or pedagogical skills. Therefore, pedagogical knowledge for teachers is knowledge that must be mastered and possessed so that the learning outcomes of students both in attitudes, knowledge, and skills can increase significantly. 


\section{Content Knowledge (CK) of Prospective Madrasah Ibtidaiyah Teachers}

Content Knowledge according to Shulman (1986), namely knowledge of concepts, theories, ideas, frameworks, knowledge of evidence, practicum, and various approaches to developing that knowledge. This understanding illustrates that all forms of knowledge related to the concept or material that will be taught to students is knowledge of content including proof of a theory through practical work in the laboratory or in the classroom and outside the classroom.

Data Scores for Content Knowledge of Prospective Madrasah Ibtidaiyah teachers on Science Learning can be seen in table 4. The average knowledge of respondent content is 2.66 with a standard deviation of 0.81 in the good category. There are three indicators of Content Knowledge in a fairly good category, namely indicators 1, 2 and 3, namely indicators of knowledge about the nature of science and its development, indicators of concepts, laws, and theories of science and their application, as well as indicators of the latest sources (such as journals) for add to the treasure of the IPA owned.

Table 4. The score of Content Knowledge questionnaire of prospective teachers of Madrasah Ibtidaiyah in natural science stream

\begin{tabular}{|c|c|c|c|}
\hline Indicator & $\mathbf{M}$ & SD & Criteria \\
\hline Knowing the nature of natural science and the development & 2.44 & 0.80 & Fairly good \\
\hline $\begin{array}{l}\text { Knowing the concepts, laws, theories of natural science and } \\
\text { their application }\end{array}$ & 2.39 & 0.83 & Fairly good \\
\hline $\begin{array}{l}\text { Utilizing the current sources, such as journal to enrich science } \\
\text { knowledge }\end{array}$ & 2.42 & 0.68 & Fairly good \\
\hline $\begin{array}{l}\text { Being able to design and apply experiment of natural science } \\
\text { for learning purposes in the classroom }\end{array}$ & 3.02 & 0.65 & Good \\
\hline $\begin{array}{l}\text { Knowing scientific approach and being able to use it for } \\
\text { learning process }\end{array}$ & 3.25 & 0.61 & Very good \\
\hline Mean & 2.66 & 0.81 & Good \\
\hline
\end{tabular}

4th Indicator, namely indicator of knowledge about designing and implementing science experiments for learning purposes in the class is in the good category with an average of 3.02 and standard deviation of 0.65 , while the average indicator is indicator of content knowledge about the scientific approach and can use it in learning process in the class is 3.25 with a standard deviation of 0.61 in the very good category.

Obtaining a very good category in the 5th indicator is very possible because respondents already have that knowledge from several courses given in class such as thematic learning subjects, social studies learning, Indonesian language learning, Mathematics learning, and science learning. The courses present some content knowledge about the scientific approach that is a characteristic of the implementation of the 2013 curriculum so that it is possible this greatly affects the knowledge of respondents about the content of the scientific approach.

Mastery of content or teaching material is very important for a teacher, because teachers as 
professional educators must convey content or concepts to students well with the aim that there is no wrong concept in its delivery (misconception). Research conducted by Murtiningsih et al. (2014) revealed that there was a positive contribution to mastery of the material to readiness to become a teacher. Thus, mastery of concepts, content, subject matter for teachers is a necessity that must be possessed as professional teacher accountability.

\section{Pedagogical Content Knowledge (PCK) of Prospective Madrasah Ibtidaiyah Teachers}

PCK is the result of integration between CK and PK in understanding how a concept or material can be taught and adapted to the heterogeneous interests and abilities of students. Content and pedagogic knowledge is the easiest category to be able to distinguish understanding of certain content from an educator. Scores of data for Pedagogical Content Knowledge of Prospective Madrasah Ibtidaiyah teachers in science learning can be seen in table 5 below.

Table 5. The score of Pedagogical Content Knowledge questionnaire of prospective teachers of Madrasah Ibtidaiyah in natural science stream

\begin{tabular}{lccl}
\hline \multicolumn{1}{c}{ Indicator } & M & SD & Criteria \\
\hline Developing curriculum & 2.41 & 0.63 & Fairly good \\
Creating lesson plans & 3.24 & 0.67 & Very Good \\
Implementing educative and dialogic instructions & 3.00 & 0.55 & Good \\
\hline \multicolumn{1}{c}{ Mean } & 3.02 & 0.67 & Good \\
\hline
\end{tabular}

Based on table 5 above, it can be analyzed that the average score of the Pedagogical Content Knowledge questionnaire for prospective teachers of Madrasah Ibtidaiyah UIN Sultan Maulana Hasanuddin Banten is in the good category (3.02) with a standard deviation of 0.67. In the table it is illustrated that for each indicator the criteria are different. The 1st indicator, namely developing the curriculum is in a fairly good category. This is possible because respondents did not yet know how to integrate curriculum content or learning into pedagogical knowledge.

In contrast to the second indicator, which is to make the implementation of the learning plan in a very good category, while the third indicator is to carry out educational and dialogical learning in the good category. This is possible because respondents already have good knowledge in preparing Learning Implementation Plans (RPP) and practicing them in several subjects such as social studies learning courses, Mathematics learning, Indonesian language learning, and science learning where the course teaches students how to plan a good implementation of learning (RPP) and teaching it in the classroom.

Content and pedagogic knowledge (PCK) is one of the knowledge that must be possessed by a teacher. PCK in a more comprehensive perspective provides an understanding of how teachers do teaching and learning well. PCK indicators include curriculum development, learning planning, and learning implementation. A study of PCK has been reviewed by several previous researchers such as in the Journal of Teacher Education (Ashton, 1990; 
Gudmundsdottir, 1990; Cochran, DeRuiter, \& King, 1993). PCK can distinguish expert teachers in teaching content or material with teachers who are experts in learning concepts or learning materials, because PCK involves how teachers relate knowledge of content or subject matter to how knowledge content or subject matter can be delivered in a pedagogical learning process.

\section{Technological Content Knowledge (TCK) of Prospective Madrasah Ibtidaiyah Teachers}

Technological Content Knowledge data scores for prospective Madrasah Ibtidaiyah teachers on Science Learning can be seen in table 6. Technological Content Knowledge is knowledge about how a teacher can associate technology and content together. Based on table 6, it can be analyzed that there are three indicators in the fairly good category. These indicators are the $2 \mathrm{nd}$, 3rd and 4th indicators, namely the indicator selects the basic competencies of the natural science / MI learning right in teaching using technology, indicators know the subject matter that requires technology facilities to facilitate students in understanding the subject matter, and indicators of the process learning with media technology such as multimedia, LCD, and laptops.

Table 6. The score of Technological Content Knowledge questionnaire of prospective teachers of Madrasah Ibtidaiyah in natural science stream

\begin{tabular}{|c|c|c|c|}
\hline Indicator & $\mathbf{M}$ & SD & Criteria \\
\hline Using technology in teaching natural science for primary schools & 2.58 & 0.63 & Good \\
\hline $\begin{array}{l}\text { Choosing basic competence for natural science course } \\
\text { appropriately when teaching using technology }\end{array}$ & 2.36 & 0.86 & Fair \\
\hline $\begin{array}{l}\text { Knowing lesson materials that need technology to ease students } \\
\text { in understanding the lesson materials }\end{array}$ & 2.43 & 0.72 & Fair \\
\hline $\begin{array}{l}\text { Implementing the instructions by utilizing technology, such as } \\
\text { multemida, LCD, and laptop }\end{array}$ & 2.37 & 0.75 & Fair \\
\hline Mean & 2.41 & 0.76 & Fair \\
\hline
\end{tabular}

Meanwhile, there is only one indicator, namely the first indicator which is in the good category. This indicator gets an average of 2.58 with a standard deviation of 0.63 . The indicator in question is an indicator of using technology in the delivery of SD / MI science subject matter. This is possible because there are some respondents who use simple technology in the delivery of science learning such as paper, markers, and images related to the concept or content of the material being taught.

Based on table 6, it can be concluded that the TCK knowledge of MI teacher candidates is in a fairly good category (2.41). This means that students of the MI UIN Sultan Maulana Hasanuddin Banten teacher are capable enough to use technology in delivering content or science materials in SD / MI, can choose the right KD by integrating technology, are quite capable of knowing materials that require the use of technology, and are quite capable do the learning process using technology such as LCD, laptop, and multimedia. The results of the analysis of TCK were also discussed by previous researchers and concluded that the 
characteristics of TCK can construct geometric shapes (Listiawan \& Baskoro, 2015). From the results of previous studies, it was seen that there was an influence of TCK on geometry material, but it had not been seen in other science materials.

\section{Technological Pedagogical Knowledge (TPK) of Prospective Madrasah Ibtidaiyah} Teachers

The data score of Technological Pedagogical Knowledge for prospective Madrasah Ibtidaiyah teachers in Science Learning can be seen in table 7 below.

Table 7. The score of Technological Pedagogical Knowledge questionnaire of prospective teachers of Madrasah Ibtidaiyah in natural science stream

\begin{tabular}{lrrr}
\hline \multicolumn{1}{c}{ Indicator } & M & SD & Criteria \\
\hline Thinking critically about using technology in the classroom & 2.83 & 0.63 & Good \\
$\begin{array}{l}\text { Using technology of information to have discussion with } \\
\text { learners }\end{array}$ & 2.43 & 0.69 & Fairly good \\
$\begin{array}{l}\text { The influence of teachers'qualifictions toward thinking } \\
\text { skills in using technology in the classroom }\end{array}$ & 2.42 & 0.89 & Fairly good \\
$\begin{array}{l}\text { Adjusting the use of technology and instructional activities } \\
\text { in the classroom }\end{array}$ & 2.80 & 0.59 & Good \\
\hline Mean & 2.65 & 0.71 & Good \\
\hline
\end{tabular}

Based on the analysis in table 7, obtained an average of 2.65 with a standard deviation of 0.71 in the good category. It is illustrated that there are two indicators that are categorized as good, namely the first indicator (thinking critically about how to use technology in class) and the fourth (adjusting the use of technology taught with classroom learning activities). While the other two indicators are in a fairly good category, namely the second indicator (using information and communication technology for discussions with students) and the third indicator (the effect of teacher education on thinking skills in the use of technology in the classroom).

Pedagogic technology knowledge is knowledge about how a technology can be used in the learning process. The existence of technology is very important in learning activities in madrasas or schools. Sahin (2011) suggests that knowledge of pedagogic technology is the integration of technology in strategies and techniques of planning learning by paying attention to various strengths and weaknesses. Thus, a teacher is required to be able to know various types of technology and their use and can use them in educational learning activities. Integration of technology can be seen in the learning activities carried out by teachers both in the classroom and outside the classroom. 


\section{Technological Pedagogical Content Knowledge (TPCK) of Prospective Madrasah Ibtidaiyah Teachers}

TPCK is a conceptual framework that integrates the three knowledge that must be mastered by the teacher, namely technology knowledge, pedagogic knowledge, and content knowledge. The TPCK conceptual framework must be mastered by the teacher so that the learning can be carried out effectively and efficiently. The Technological Pedagogical Content Knowledge data score for prospective Madrasah Ibtidaiyah teachers in science learning can be seen in table 8 below.

Table 8. The score of Technological Pedagogical Content Knowledge questionnaire of prospective teachers of Madrasah Ibtidaiyah in natural science stream

\begin{tabular}{lrrrl}
\hline \multicolumn{1}{c}{ Indicator } & M & SD & Criteria \\
\hline $\begin{array}{l}\text { Using a strategy combining technology, instructional approach, and } \\
\text { content of natural science for primary school }\end{array}$ & 2.44 & 0.73 & Fair \\
$\begin{array}{l}\text { Providing models in helping others to coordinate the using of } \\
\text { technology, approach, and content }\end{array}$ & 2.38 & 0.75 & Fair \\
$\begin{array}{l}\text { Choosing the use of technology in the classroom that can inprove } \\
\text { the quality of learning, teaching, and students learn }\end{array}$ & 2.44 & 0.76 & Fair \\
$\begin{array}{l}\text { Teaching appropriate materials by integrating technology, methods, } \\
\text { and the content of the lesson. }\end{array}$ & 2.32 & 0.76 & Fair \\
$\begin{array}{l}\text { Teaching the content of the materials that are appropriate with the } \\
\text { pedagogical competence and can utilize technology in teaching } \\
\text { materials to the learners }\end{array}$ & 2.28 & 0.75 & Fair \\
\hline \multicolumn{1}{c}{ Mean } & 2.38 & 0.75 & Fair \\
\hline
\end{tabular}

Based on table 8, the data obtained from the Technological Pedagogical Content Knowledge questionnaire score or TPCK for prospective students of UIN Madrasah Ibtidaiyah teacher Sultan Maulana Hasanuddin Banten. The average questionnaire score of 2.38 with a standard deviation of 0.75 is in the fairly good category. Likewise, it can be seen in all indicators of Technological Pedagogical Content Knowledge or TPCK which show quite good categories. These indicators include: 1) using strategies that combine technology, learning approaches, and SD / MI science content, 2) providing exemplary in helping others to coordinate technology use, teaching approaches in schools, and content, 3) choosing technology use in class that can improve the quality of the learning process, how I teach, and what learners learn, 4) teach the right material content by integrating technology, methods, and learning content, and 5) teach material content that is compatible with pedagogical competencies and can use learning technology in teaching material to students.

The same thing is also shown by the Technological Pedagogical Content Knowledge (TPCK) score on the Science Learning Implementation Plan. Based on table 8, the average score of Technological Pedagogical Content Knowledge (TPCK) is 0.59 with a standard deviation of 0.50. This score shows a fairly good category. This means that the Learning Implementation 
Plan made by respondents is quite good in fulfilling the Technological Pedagogical Content Knowledge (TPCK) element.

Table 9. Score of Technological Pedagogical Content Knowledge (TPCK) of prospective teachers of Madrasah Ibtidaiyah in natural science stream

\begin{tabular}{ll}
\hline Description & Technological Pedagogical Content Knowledge (TPCK) \\
\hline $\mathrm{N}$ & 78 \\
Mean & 0.59 \\
Standard Deviation & 0.50 \\
Category & Fairly good \\
\hline
\end{tabular}

The percentage of Technological Pedagogical Content Knowledge or TPCK questionnaire results can be seen in Figure 1. The figure illustrates that the percentage of Technological Pedagogical Content Knowledge or TPCK questionnaires is in the fairly good category of $62 \%$ or 48 respondents, while the percentage of Technological Pedagogical Content Knowledge or TPCK is in the good category of $38 \%$ or as many as 30 respondents. The results of direct observation also indicate that the TPCK of prospective student Madrasah Ibtidaiyah teachers in science learning shows sufficient criteria.

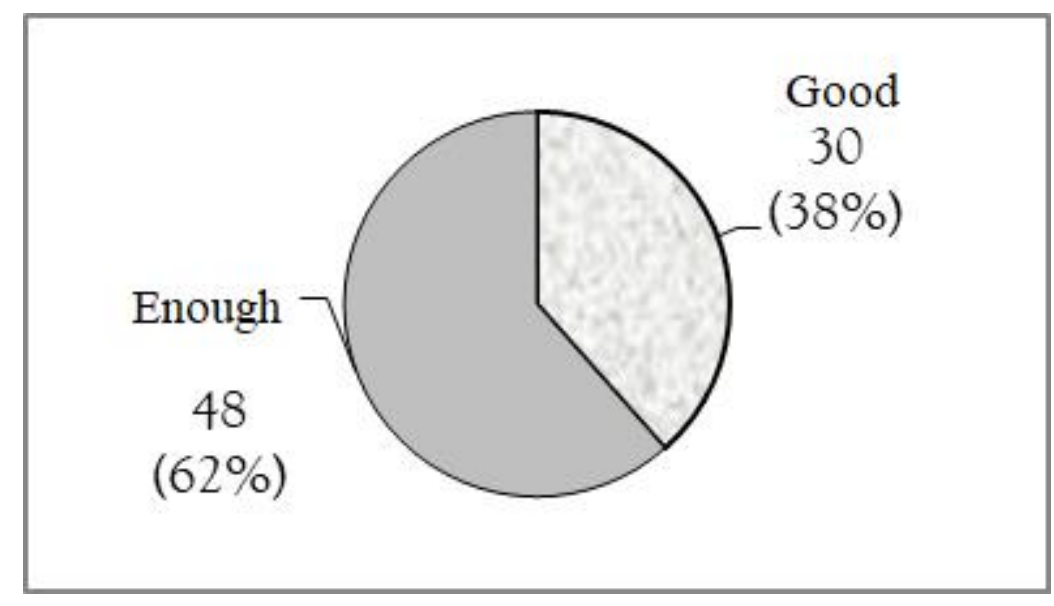

Figure 1. Percentage of the results of TPCK questionnaire for prospective teachers of Madrasah Ibtidaiyah in natural science stream

Based on table 9 and figure 1, it can be concluded that the knowledge of the TPCK of the prospective teacher of MI UIN Sultan Maulana Hasanuddin Banten is in a fairly good category. This means that prospective MI teacher students have sufficient knowledge in the TPCK. The integration of technology into material learning or certain content is a whole conceptual framework. Teachers and prospective teachers are required to have knowledge and a comprehensive understanding of the interactions between the three basic components of knowledge, namely PK, CK, and TK by teaching and learning certain science concepts in accordance with pedagogical and technological methods that are appropriate for students (Schmidt et al., 2009). 


\section{CONCLUSION}

Based on the description of the results of the research presented, it can be concluded that the skills of Technological Pedagogical Content Knowledge (TPCK) candidates for Madrasah Ibtidaiyah on Science Learning are in a fairly good category. Good TPCK knowledge will greatly influence the learning process carried out by prospective teacher and teacher students, how it teaches and teaches educative concepts with the help of existing technology both simple technology and modern technology. Integration of technology into learning material, content, or certain concepts is a whole conceptual framework that is interconnected with other knowledge, namely technology, pedagogics, and content. Teachers and teacher candidates are required to have comprehensive knowledge and understanding of the interactions between the three basic components of knowledge, namely PK, CK, and TK by teaching and learning certain science concepts in accordance with methods that educate and use appropriate technology to students. Thus, hoping to become a professional teacher who has four competencies, two competencies will be fulfilled, namely pedagogic competence and professional competence.

\section{REFERENCES}

Andriawati, E., Mashudi, \& Utomo, B. B. (2013). Pengaruh Kompetensi Pedagogik Guru terhadap Hasil Belajar Siswa pada Pembelajaran Ekonomi di SMA. Jurnal Pendidikan dan Pembelajaran, 2(10).

Arna. (2014). Penyebab Guru Tidak Menggunakan RPP dalam Pembelajaran. Pendidikan Sosiologi, 1(1), 1-11.

Ashton, P. (1990). Editorial. Journal of Teacher Education, 41(3).

Cochran, K. F., DeRuiter, J. A., \& King, R. A. (1993). Pedagogical Content Knowing: An Integrative Model for Teacher Preparation. Journal of Teacher Education, 44(4), 263272. https://doi.org/10.1177/0022487193044004004

Cox, S., \& Graham, C. R. (2009). Diagramming TPACK in Practice: Using an Elaborated Model of the TPACK Framework to Analyze and Depict Teacher Knowledge. TechTrends, 53(5), 60-69. https://doi.org/10.1007/s11528-009-0327-1

Creswell, J. W. (2009). Research Design; Qualitative, Quantitative, and Mixed Methods Approarches. Los Angeles: Sage.

Edy, I. C. (2012). Pengaruh Penerapan Teknologi Informasi dan Komunikasi (TIK) terhadap Hasil Belajar Siswa SMU/SMK di Surakarta. Jurnal Ekonomi Bisnis dan Perbankan (PROBANK), 17(1), 1-11.

Gudmundsdottir, S. (1990). Values in Pedagogical Content Knowledge. Journal of Teacher Education, 41(3), 44-52. https://doi.org/10.1177/002248719004100306

Kabakci Yurdakul, I., Odabasi, H. F., Kilicer, K., Coklar, A. N., Birinci, G., \& Kurt, A. A. (2012). The development, validity and reliability of TPACK-deep: A technological pedagogical content knowledge scale. Computers \& Education, 58(3), 964-977. https://doi.org/10.1016/j.compedu.2011.10.012 
Koçoğlu, Z. (2009). Exploring the Technological Pedagogical Content Knowledge of PreService Teachers in Language Education. Procedia - Social and Behavioral Sciences, 1(1), 2734-2737. https://doi.org/10.1016/j.sbspro.2009.01.485

Koehler, M. J., Mishra, P., Kereluik, K., Shin, T. S., \& Graham, C. R. (2014). The Technological Pedagogical Content Knowledge Framework. In J. M. Spector, M. D. Merrill, J. Elen, \& M. J. Bishop (Eds.), Handbook of Research on Educational Communications and Technology (pp. 101-111). https://doi.org/10.1007/978-1-4614-3185-5_9

Koehler, M., \& Mishra, P. (2009). What is Technological Pedagogical Content Knowledge (TPACK)? Contemporary Issues in Technology and Teacher Education, 9(1), 60-70.

Ling Koh, J. H., Chai, C. S., \& Tay, L. Y. (2014). TPACK-in-Action: Unpacking the contextual influences of teachers' construction of technological pedagogical content knowledge $\begin{array}{lllll}\text { (TPACK). Computers } \quad \& \quad \text { Education, } & \text { 20 }\end{array}$ https://doi.org/10.1016/j.compedu.2014.04.022

Listiawan, T., \& Baskoro, W. W. (2015). Analisis Technological Content Knowledge (TCK) Calon Guru Matematika Dalam Menggunakan Perangkat Lunak Geometri Dinamis. 7.

Murtiningsih, Y. J., Susilaningsih, \& Sohidin. (2014). Pengaruh Penguasaan Materi Mata Kuliah Dasar Kependidikan (MKDK) dan Praktik Program Pengalaman Lapangan (PPL) terhadap Kesiapan Menjadi Guru. Jupe-Jurnal Pendidikan Ekonomi, 2(3), 323-337.

Owusu, K. A., Monney, K. A., Appiah, J. Y., \& Wilmot, E. M. (2010). Effects of ComputerAssisted Instruction on Performance of Senior High School Biology Students in Ghana. Computers \& Education, 55(2), 904-910. https://doi.org/10.1016/j.compedu.2010.04.001

Peraturan Pemerintah Republik Indonesia Nomor 74 Tahun 2008 tentang Guru

Rau, P.-L. P., Gao, Q., \& Wu, L.-M. (2008). Using Mobile Communication Technology in High School Education: Motivation, Pressure, and Learning Performance. Computers \& Education, 50(1), 1-22. https://doi.org/10.1016/j.compedu.2006.03.008

Sahin, I. (2011). Development of Survey of Technological Pedagogical and Content Knowledge (TPACK). The Turkish Online Journal of Educational Technology, 10(1), 97-105.

Sari, A. P. (2013). Pengaruh Penguasaan Kompetensi Pedagogik Guru terhadap Hasil Belajar IPA pada Siswa Kelas 3 di SD Muhammadiyah I6 Karangasem Surakarta Tahun Ajaran 2012/2013 (Universitas Muhammadiyah Surakarta). Retrieved from http://eprints.ums.ac.id/24527/

Schmidt, D. A., Baran, E., Thompson, A. D., Mishra, P., Koehler, M. J., \& Shin, T. S. (2009). Technological Pedagogical Content Knowledge (TPACK): The Development and Validation of an Assessment Instrument for Preservice Teachers. Journal of Research on Technology in Education, 42(2), 123-149.

Shulman, L. S. (1986). Those Who Understand: Knowledge Growth in Teaching. Educational Researcher, 15(2), 4-14.

Sugiyono. (2013). Metode Penelitian Pendidikan: Pendekatan Kuantitatif, Kualitatif, dan R\&D. Bandung: Alfabeta.

Sugiyono. (2017). Statistika untuk Penelitian. Bandung: Alfabeta.

Sumintono, B., Wibowo, S. A., Mislan , N., \& Tiawa, D. H. (2012). Penggunaan Teknologi Informasi dan Komunikasi dalam Pengajaran: Survei pada Guru-Guru Sains SMP di Indonesia. Jurnal Pengajaran MIPA, 17(1), 122-131.

Tim Penyusun. (2018). Pedoman Praktik Pengalaman Lapangan Kependidikan. Serang: Fakultas Tarbiyah dan Keguruan UIN Sultan Maulana Hasanuddin Banten. 
Valanides, N. (2014). Technological Pedagogical Content Knowledge. New York: Springer.

Wiguna, R., Fitri, Z., \& Erlidawati. (2017). Kompetensi Technological Pedagogical And Content Knowledge Pada Mahasiswa Program Praktik Lapangan Program Studi Pendidikan Kimia Semester Ganjil Tahun Ajaran 2016/2017. Jurnal Ilmiah Mahasiswa Pendidikan Kimia, 2(2).

Yaumi, M. (2011). Integrasi Teknologi Informasi dan Komunikasi dalam Pembelajaran. Lentera Pendidikan, 14(1), 88-102

Yusri. (2016). Pengaruh Penggunaan Media Teknologi Informasi dan Komunikasi (TIK) dengan Prestasi Belajar Bahasa Inggris Peserta Didik Kelas X di SMAN I Dekai Kabupaten Yahukimo. Jurnal Ilmiah ILKOM, 8(1), 49-56. 